\author{
Journal of Asian Business Strategy \\ $\operatorname{ISSN}(e): 2225-4226$ \\ $\operatorname{ISSN}(p): 2309-8295$ \\ DOI: 10.18488/journal.1006/2018.8.1/1006.1.1.14 \\ Vol. 8, No. 1, 1-14. \\ (C) 2018 AESS Publications. All Rights Reserved. \\ URL: www.aessweb.com \\ check for
updates
}

\title{
PRIVATIZATION AND PROFIT EFFICIENCY: EVIDENCE FROM
COMMERCIAL BANKS OF PAKISTAN
}

\author{
Samina Sabir ${ }^{1+}$ \\ Abdul Qayyum²
}

\author{
'Kashmir Institute of Economics, University of Azad Jammu and Kashmir, \\ Muzaffarabad, Pakistan. \\ Email:samina.sabir78@gmail.com \\ (+ Corresponding author) \\ "Kashmir Institute of Economics, University of Azad Jammu and Kashmir, \\ Muzaffarabad, Pakistan.
}

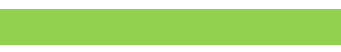

\section{Article History}

Received: 30 April 2018 Revised: 4 June 2018

Accepted: 11 August 2018

Published: 27 August 2018

\section{Keywords:}

Banking efficiency

Profit,

Panel data.

\begin{abstract}
This paper investigates the profit efficiency of commercial banks where the banking sector has completed more than two decade of changeover from nationalization policy to privatization and restructuring policy by employing stochastic frontier true effect and true random effect models. Intermediation approach has been used to choose input and output variables of banks. A balanced panel data of 22 commercial banks of Pakistan over the period 1995-2014 have been used for the empirical analysis. The paper found that commercial banks are on average $73 \%$ profit efficient. However foreign banks report high profit efficiency score followed private domestic banks and then state owned banks. We also compared the cost and profit efficiency of commercial banks and found that commercial banks are more cost efficient than profit efficient.
\end{abstract}

Contribution/ Originality: In case of Pakistan, there are limited literature available on the profit efficiency of commercial banks. Therefore this paper contributes in the literature by examining the profit efficiency of commercial banks operating in Pakistan after the reforms period.

\section{INTRODUCTION}

The concept of efficiency has been introduced by Debreu (1951) and Koopmans (1951), and further disaggregated by Farrell (1957) into allocative and technical efficiency. The mean of efficiency lies between zero and one. If it is equal to one, then banks are operating on efficiency frontier implies that factor input are being used optimally to produce output. Whereas efficiency score equal to zero means banks are inefficient in the allocation of resources.

More competitive, stable and well capitalized banking sector would channel savings to the more productive projects to facilitate growth process (Levine, 1997). With this in mind, in late 1980 s and 1990s, the government of Pakistan has liberalized the banking sector by privatizing national commercial banks, entry of private and foreign banks, branch liberalization and implementation of 
Basel Accord (I, II and III) to strengthen capital base and interest rate liberalization (Sabir and Qayyum, 2018). Initially the banking sector was highly concentrated but the restructuring and privatization of state owned banks, new entry of private banks and consolidation of banks provide level playing field and also increased the competition in the banking sector ${ }^{1}$. Since 2003, advanced technology and product innovation has been emerged in the banking sector in the form of ebanking, automated teller machines (ATMs), core and mobile banking.

A number of studies have been conducted to assess the impact of banking sector reforms on the allocation of resource through cost efficiency (Burki and Niazi, 2009; Qayyum and Khan, 2007; Hardy and Patti, 2001 and Rizvi, 2001).

Internationally many studies have been carried out to check the impact of financial reforms on profit efficiency (Akhavein et al., 1997; Vivas, 1997; Kumbhakar et al., 2001; Hasan and Marton, 2003; Reddy and Nirmala, 2013) while in Pakistan Hardy and Patti (2001) have examined the impact of financial reforms on the profit efficiency of commercial banks over the period 1989-2002. They used limited data-set spanning a period during which banking sector reforms were not even entirely implemented. The objective of this paper is to examine the profit efficiency of commercial banks of Pakistan using true fixed effect model and true random effect model to encounter unobserved heterogeneity exists among commercial banks.

In Pakistan, profit efficiency of commercial banks has not been studied extensively due to major focus of researchers and academician on cost efficiency of banks. Indeed, profit efficiency is an extensive concept than cost efficiency because it encompasses both input and output oriented efficiencies.

We emphasize in this paper on output oriented inefficiency that is estimated through profit function. There are certain reasons to study efficiency through profit function than the cost function; first technical efficiency and allocative efficiency can be better studied through profit function to examine the impact of financial reforms and consolidation because reforms allow the allocation and distribution of inputs and outputs among banks; secondly, product quality leads to lower inefficiencies. Production of quality products requires higher cost but higher quality products generate more revenues. Higher revenues offset the increase in cost to produce goods and services. Thirdly, profit function provides the way to estimate output oriented efficiency by incorporating revenue side of the firm (Berger, 1993).

Profit function is preferred to cost function because cost function only discusses the technical efficiency whereas profit function discusses both input and output efficiency (Mullineaux, 1978; Berger et al., 1997). To analyze the profit efficiency of the banks, we employ Intermediation approach to select input and output variables.

To control interbank heterogeneity, stochastic frontier approach is used based true fixed effect and true random effect model developed by Greene (2005a) to examine the profit efficiency of the 22 commercial banks. We collect the most recent data of commercial banks from annual income reports of banks, financial statements of banks and banking statistics of state bank of Pakistan over the period 1995-2014.

We compare the cost efficiency with profit efficiency of banks. For sake of comparison, we also measure effect of deregulation on profit efficiency of private commercial banks, foreign banks and state owned banks. Ray and Das (2010) have reported their findings on the impact of banking reform on the cost and profit efficiency of Indian banks. We consider here the case of banks operating in Pakistan. They used DEA approach to measure cost and profit efficiency of banks. We

${ }_{1}$ This privatization and restructuring policy reduce the total assets share of state owned banks from $93 \%$ in 1990 to $22 \%$ in 2004 (Burki and Niazi, 2010; State Bank of Pakistan (SBP), 2005). 
have used a true fixed effect and true random effect model to estimate the profit efficiency of banks because these methods capture the heterogeneity exists among commercial banks.

This paper is divided into six sections. Section 2 provides a detailed review of literature on efficiency of the banks. Section 3 presents also the theoretical framework of efficiency. Section 4 explains the methodology of the paper, which includes empirical model of alternative profit function and provides information about data sources and construction of variables. Section 5 presents the results and discussion of profit efficiency. Section 6 provides conclusions.

\section{LITERATURE REVIEW}

Many developing and developed countries have undergone the process of deregulation since 1989. This process of deregulation and liberalization involves restructuring and privatization of state owned banks, opening of private banks, interest rate and easing of branch policy. We focus on developing country like Pakistan, in this literature survey because the quality of governance is different.

For example, Chakravarty and Williams (2006) find that the state-owned municipal banks in Germany are performing better than the large commercial banks quoted on bourses. Vivas (1997) investigates the impact of deregulation on the profit efficiency of Spanish saving banks over the period 1986-1991. His study uses alternative and standard profit function in his analysis of efficiency by using thick frontier approach (TFA). This study concludes that deregulation has improved the profit efficiency of Spanish saving banks. Kumbhakar et al. (2001) explore the effects of regulatory reforms on the profit efficiency of Spanish banks over the period 1986-1995 and use value added approach to define input and output variables. Their study finds that deregulation has significant and positive effect on profit efficiency and productivity growth due to increase in competition.

Moreover Reddy and Nirmala (2013) examine the profit efficiency of commercial banks in India using Stochastic Frontier Approach after the post reforms period. Their analysis reveal that state own banks are more efficient among domestic private banks and foreign commercial banks. Phang and Raweewan (2015) estimate the cost, revenue and profit efficiency of the commercial banks functioning in Cambodia using DEA approach. They conclude that big banks are higher profit, revenue and cost efficient than smaller banks while foreign commercial banks are more profit efficient than Cambodian commercial banks.

In developing countries, numerous studies have explored the profit efficiency of banks in different countries but in case of Pakistan it is difficult to find any study which has examined profit efficiency of commercial banks of Pakistan. For example, Hardy and Patti (2001) inspect the impact of financial liberalization on the profit, revenue and cost efficiency of commercial banks of Pakistan over the period 1981-1997. Their finding reveal that state owned banks are profit inefficient compared to other banks. But with the passage of the time, profit efficiency improves over the time. Performance of newly established private commercial banks has not improved compared to other commercial banks.

Data used for this do not truly reflect the impact of financial reforms on the efficiency because time period selected for the study only reflect the preliminary impact of financial reforms. Actually financial reforms were not implemented during this time period. Therefore, we cannot draw a plausible conclusion from their results. A number of studies have examined the cost efficiency of the commercial banks. For example Iimi (2004) examine impact of banking sector reforms on the economies of scale and scope, and cost complementarities of 41 commercial banks over the period 1998-2001. Intermediation approach is used for variable selection. They find that $20 \%$ of diseconomies of scale prevailed in large banks. However, medium and small banks take the advantage of economies of scales as compared to large banks. However, national commercial banks have large asset shares in banking industry but they are working under decreasing return to scale. 
Foreign banks are availing economies of scale but private and foreign banks both attain low economies of scope.

Patti and Hardy (2005) observe the impact of privatization on the cost and profit efficiency of commercial banks in Pakistan over the period 1981 to 2002. Intermediation approach is used to define input and output variables. This study finds that commercial banks are $20 \%$ cost efficient but profit efficiency is recorded higher than cost efficiency. In the second period of reforms, foreign banks are found to be less profit inefficient than newly private domestic banks. Foreign and domestic banks are best practiced banks. Profit efficiency of the banks declined in the third phase of reforms from 1998-2002. Interesting finding of this study is that the private banks outperform the foreign banks.

Similarly, Qayyum and Khan (2007) examine the X-efficiency, scale economies, and technological progress of the 29 banks operating in Pakistan over the period 1998-2005. DFA is used to estimate the cost efficiency of the banks employing Fourier flexible functional form. They find that foreign banks are more scale efficient than domestic and big banks. Akmal and Saleem (2008) estimate the technical efficiency of 30 commercial banks in Pakistan by using DEA over the period 1995 to 2005. They conclude that banking sectors is $91 \%$ efficient in VRS. State owned banks are $88 \%$ efficient, local private banks are $91 \%$ efficient and foreign banks are $93 \%$ efficient. They conclude that foreign banks are more efficient than private and domestic banks. They also find that banks are $96 \%$ scale efficient. They suggest that banks can improve their efficiency by increasing loans and branch network size.

Later on Burki and Niazi (2009) investigate the impact of financial sector reforms on the efficiency of commercial banks in Pakistan. They use DEA approach for efficiency analysis. Input and output variables are selected through intermediation approach. Results reveal that banking sector is $74.5 \%$ efficient.

Allocative and technical efficiencies declined more than $90 \%$ in 1991 to less than $75 \%$ in 1996 . They conclude that private and foreign banks performed better than state owned banks. Burki and Ahmad (2010) examine the impact of governance on the cost efficiency of commercial banks in Pakistan over the period of 1991-2005 using Battese and Coelli (1995) single equation method to estimate efficiency. They find that banks have mean efficiency score of $136.1 \%$. They observe that private banks are more efficient than the foreign and state owned banks. Efficiency of newly privatized commercial banks declined over the time.

Though a number of studies have estimated the cost efficiency of commercial banks operating in Pakistan. However, we are unable to find any comprehensive study which has estimated the effects of financial liberalization on profit efficiency of banks in Pakistan. Therefore, we fill this gap in literature by using econometric techniques based on true fixed effects and true random effect models. We also compare the profit efficiency of state own commercial banks, private commercial banks and foreign banks.

\section{THEORETICAL FRAMEWORK}

Given the output prices and input prices, commercial banks produces the maximum quantity of output at given input prices and input quantities that maximize its profit. Therefore banks produces maximum output quantity at minimum cost. To evaluate the performance of the banks, now frontier shifts from revenue to profit frontier. Profit efficiency is comprised of output oriented efficiency and input oriented efficiency. Profit efficiency is the ratio between observed profit and maximum profit.

This can be explained with the help of figure 1. If maximum level of output $Y^{*}$ is produced by commercial bank. At this output level, profit is maximized and profit efficiency is equal to 1 . For all 
other input-output combination, profit efficiency is less than 1. We assume that output is produced by one factor input ' $\mathrm{X}$ ' given the measured technology.

If firm produces, another level of output say 'Y1', then it will be technically inefficient level of output, which will reduce the revenues of the bank. Figure 1 shows that the difference between $Y$ and $Y^{*}$ is referred as technical inefficiency. If the bank produces the output below ' $\mathrm{Y} 1$ ' such as $\mathrm{Y} 2$, then profit of the firm will decline and profit inefficiency will increase due to technical and allocative inefficiency. But if the bank output is towards ' $\mathrm{Y}^{*}$ ' then its profit will increase that will lead to profit efficiency. It is non-decreasing in output prices and non-increasing in input prices. Profit efficiency is greater than equal to 1.

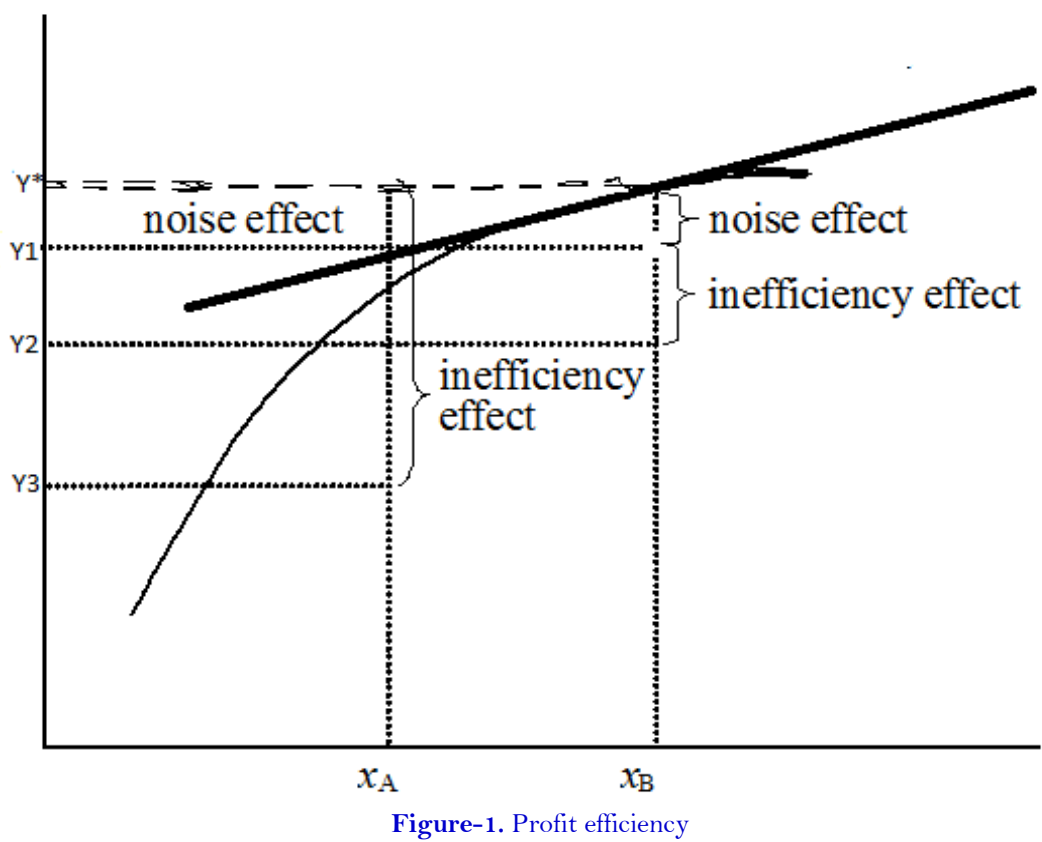

\subsection{Profit Maximization Theory}

Commercial banks use labor and capital as factor inputs to produce output quantities like deposits, loan and advances and investment. We can generalize the production function for the banks as

$$
Y=f(x)
$$

Where $\mathrm{Y}$ is the vector of output variables and $\mathrm{x}$ is the vector of input variables. This production function is non-negative and concave in input price. Banks, like other firms, try to maximize the output by using its inputs optimally. This leads to Pareto efficiency and social welfare. Shepherd (1970) mentions that the properties of production function can be studied in a useful way by using cost function and profit function.

Objective of the bank is to maximize profit by generating more revenues and minimizing cost of production. Therefore, profit function of perfectly competitive bank is the function of input prices and output prices (McFadden, 1966). In production theory, profit stems from output during the production process. Profit function satisfies the properties of convexity, non-negativity, increasing in output prices, decreasing input prices and increasing in the quantities of fixed factor inputs (Mullineaux, 1978). However, banking market is usually non-competitive banks, non-standard or alternative profit function (NSPF) is used to study the technical and allocative efficiency of the banking sector. Alternative profit function is preferred to standard profit function if i) there exists 
difference in the quality of the product produced by banks; ii) banking products are not variable and banks are unable to achieve economies of scale and mix; iii) product market is not perfectly competitive, so banks use their market power to set output price to some extent; iv) data on output prices are not available with required degree of disaggregation (Berger and Mester, 1997) ${ }^{2}$. In $\mathrm{NSPF}$, output quantities and input prices are exogenously determined whereas input quantities and output prices are endogenous (Berger and Mester, 1997; Kumbhakar, 2006). Profit maximization problem of noncompetitive banks with output oriented inefficiency can be written as

$$
\operatorname{Max} \pi=p y-w x
$$

Subject to $f(y, x) e^{-u}=0$

In this equation $g(y, w, p)=0$ is a price opportunity set to transform $\mathrm{y}$ and $\mathrm{w}$ into output prices (Humphrey and Pulley, 1997). Where $y$ is the vector of output variables such as loan, non-interest income and interest income, $x$ is the vector of input variables such as labor, physical capital and deposits, $p$ is the vector of prices of output, $w$ is the vector of input prices and $u \geq 0$ is the output oriented inefficiency. $M P_{x}=\frac{\partial f(y, x)}{\partial x}$ is the marginal product of input variable $\mathrm{x}$. let $\tilde{p}=e^{-u} p$ and $\tilde{y}=e^{-u} y$ and substitute $\tilde{p}$ and $\tilde{y}$ in equation (1).

$$
\operatorname{Max} \pi=\tilde{p} \tilde{y}-w x
$$

Subject to $f(\tilde{y}, x)=0$

This optimization problem can be solve by applying first order condition on equation (2) to find out output price $(\tilde{p})$ and input demand $(x)$. Therefore output price and input demand are the function of $\tilde{y}$ and $w$ respectly.

$$
\begin{gathered}
\tilde{p}=f_{\tilde{p}}(\tilde{y}, w) \\
x=f_{x}(\tilde{y}, w)
\end{gathered}
$$

Indirect profit function would be

$$
\begin{aligned}
& \operatorname{Max} \pi=\tilde{p}(\tilde{y}, w) \tilde{y}-\dot{w} x(\tilde{y}, w) \\
& =R\left(y e^{-u}, w\right)-C\left(y e^{-u}, w\right)=\pi\left(y e^{-u}, w\right)
\end{aligned}
$$

We can define the profit frontier as

$$
\pi(y, w)=\left.\pi\left(y e^{-u}, w\right)\right|_{u=0}
$$

Following relation can be established

$$
\begin{aligned}
\pi & =\pi\left(y e^{-u}, w\right)=\pi(y, w) \cdot h(y, w, u) \\
\ln \pi & =\ln \pi\left(y e^{-u}, w\right)=\ln \pi(y, w)+\operatorname{lnh}(y, w, u)
\end{aligned}
$$

Where $\ln u=\frac{\pi\left(y e^{-u}, w\right)}{\pi(y, w)} \geq 1, \ln u \leq 0$, this result is associated with monotonicity property of profit function of banks i.e. $y e^{-u} \leq \pi\left(y e^{-u}, w\right) \leq \pi(y, w)$.

\footnotetext{
2 See the article "Inside the block box: What explains the differences in the efficiencies of financial institutions?"
} 
Above equation (7) shows that indirect profit can be disaggregated into profit frontier and profit inefficiency. This indirect profit function is not homogenous of degree 1 because a twice increase in input quantities and output prices will increase profit more than twice due to market power of the firm (Vivas, 1997; Humphrey and Pulley, 1997; among others).

Alternative profit function of noncompetitive banks is introduced by Berger (1993) and it can be written as

$$
\ln \left(\pi_{i t}+\theta\right)=f\left(y_{i t} e^{-u}, w_{i t}\right)-\ln u_{i}+\ln v_{i t}
$$

In equation (8) $i$ presents number of commercial banks $(i=1,2, \ldots, \mathrm{N}), \mathrm{t}$ is the time period $(t=$ $1,2, \ldots, \mathrm{T}), \pi$ is profit of banks before tax and $\theta$ is the scalar added in profit in order to avoid the negative value of profit.

On the right hand side, ' $y$ represents the vector of output produced by the banks; and ' $w$ ' is the vector of input prices. 'Inu' is the inefficiency term which shows that banks profit deviate from the best practiced bank. ' $l n v$ ' is the random error term which shows the deviation of the banks profit from maximum profit earned by efficient bank due to white noise term. $\ln u \geq 0$ and lnv can be positive or negative (Bauer and Ferrier, 1996). Alternative profit efficiency is ratio of actual profit and predicted maximum profit of best practice bank.

$$
\pi_{e f f}=\frac{\widehat{a \pi}}{\widehat{\pi}_{\max }}
$$

Output price will affect the efficiency but output quantity will not affect the efficiency. Efficiency score lies between 0 and 1 (Berger and Mester, 1997).

Similarly we can find out input oriented inefficiency by solving following maximization problem

$$
\begin{aligned}
& \operatorname{Max} \pi=\tilde{p} \tilde{y}-\tilde{w} \tilde{x} \\
& \text { Subject to } \quad f(y, \tilde{x})=0
\end{aligned}
$$

By using analytical technique, we get following function

$$
\begin{gathered}
\pi=\pi\left(y, w e^{-\mu}\right)=\pi(y, w) \cdot h(y, w, \mu) \\
\ln \left(\pi_{i t}+\theta\right)=f\left(y_{i t}, w_{i t} e^{-\mu}\right)-\ln \mu_{i}+\ln v_{i t} \quad \ldots \ldots \ldots
\end{gathered}
$$

\section{METHODOLOGY AND DATA}

Panel data stochastic frontier approach of Greene (2005a) for fixed effect model (FEM) and random effect model (REM) is used to estimate the output oriented efficiency of commercial banks of Pakistan. Main advantage of using Greene (2005a) true fixed effect model (TFEM) is that it considers the heterogeneity exists among banks and captures it through separate intercept for each bank or cross section. We consider linear stochastic fixed effect alternative profit function is specified as,

$$
\ln \left(\pi_{i t}+\theta\right)=\alpha_{i}+y_{i t}^{\prime} \beta+\ln w_{l t} \gamma+v_{i t} \pm \hat{\mathrm{u}}_{\mathrm{it}}
$$

where, $\alpha_{i}$ is a heterogeneous intercept for each bank, subscript i and t denoting commercial banks and years respectively. TFEM is estimated using Maximum likelihood dummy variable method. In this method, we estimate profit inefficiency of bank as follows: 


$$
\hat{\mathrm{u}}_{\mathrm{it}}=\left|\mathrm{U}_{i t}\right| \sim \mathrm{N}\left(\left(\mu_{i}, \delta_{u i}^{2}\right)\right.
$$

This clearly indicates that all $\hat{u}_{i t} \geq 0, \delta_{u}$ has exponential distribution.

True random effect model can be written as

$$
\ln \left(\pi_{i t}+\theta\right)=\alpha+y_{i t}^{\prime} \beta+\ln w_{l t}^{\prime} \gamma+\Psi_{i} \pm u_{i t}+v_{i t}
$$

$v_{i t}$ has exponential distribution, $\Psi_{i}, u_{i t}$ and $v_{i t}$ are uncorrelated with each other, $u_{i t}$ measures inefficiency (efficiency) and $\Psi_{i}$ has normal distribution and it captures the unobserved heterogeneity exist among banks. This model is estimated by using maximum simulated likelihood method.

\subsection{Data and Construction of Variable}

This paper considers the panel data of 22 commercial banks which consists of 2 stated own commercial banks, 5 foreign banks and 15 domestic private commercial banks. Data are obtained from banking statistics of State Bank of Pakistan, annual reports of the banks, balance sheets of the banks and economic Bulletin of National Bank of Pakistan.

For instance, intermediate approach ${ }^{3}$ introduced by Sealey and Lindley (1977) is used to define the input and output variables. By following the studies of Maudos et al. (2002) and Berger and Mester (1997) labor, capital and loanable funds or deposits are treated as input variables and total loans and investment are measured as output variables. Sealey and Lindley believe that only those goods which have higher market value than its original form can be considered the output of the financial firms or banks.

We calculate the price of labor by taking the ratio of administrative expenses(wages, fringe benefits and other allowances) and total number of the employees by following the studies of Altunbas et al. (2001), Berger and Mester (1997), Hughes et al. (1996a), and Poshakwale and Qian (2011). Price of the physical capital is obtained by dividing expenditures on plant and equipment by book value of the physical capital. Price of loanable fund is the ratio between interest paid and total deposits.

Efficiency depicts the difference between optimal profit and actual profit that has been realized. Any deviation from the best frontier is due to inefficiency. It is necessary to consider the other factors which could affect efficiency in addition to the traditional factors or measures. Efficient banks must be solvent and prudent in term of risk preferences.

Therefore, it is worthwhile to include the standard measure of risk of insolvency in the efficiency measurement; because financial firm holds the equity or financial capital to absorb any investment and financial default, portfolio losses and portfolio risk. Financial capital or risk of insolvency affects the financial firm's profit and cost through risk premium, which bank has to pay for uninsured debt and risk management activities. Sometimes interest rates paid on deposits compensate the difference in the risk but these rates are not accurately (imperfectly) measured (Berger and Mester, 1997).

If risk is kept aside even then financial capital affects the cost and profit of the banks; reason for this is that it is the alternative of deposits, which are used as a funding source for loans. If banks increase the level of the equity, their cost will increase more than the increase in the deposits. If equity-raising is greater than the deposit's raising realized cost will be higher for banks due to debt financing. If the deposit raising is higher, then vice versa result is obtained. Usually large banks 3 The intermediation approach has been used in previous studies on efficiency of banks (Berger and Mester, 1997; Isik and Hassan, 2002;
Burki and Niazi, 2009; Burki and Ahmad, 2010 respectively). 
rely more on debt financing than the small banks. More risk-averse banks prefer to enhance their financial capital than to maximize the profits or minimize the cost. Descriptive statistic of the variables is given in table1.

By following the studies of Hughes et al. (1995); Hughes and Mester (1993, 1996), Berger and Mester (1997); Altunbas et al. (2001), and Ray and Das (2010), we incorporate financial capital in this model to determine the profit efficiency of the commercial banks functioning in Pakistan.

Table-1. Descriptive statistics

\begin{tabular}{l|c|c|c|c|c}
\hline & Mean & Maximum & Minimum & Std. dev. & Obs. \\
\hline $\begin{array}{l}\text { Profit before tax (Million } \\
\text { rupees) }\end{array}$ & 3814.779 & 48514.810 & 0.400 & 7316.932 & 440 \\
\hline Total cost (Million rupees) & 34595.870 & 5109031.000 & 0.595 & 300089.500 & 440 \\
\hline Loan (Million rupees) & 319091.500 & 106000000.000 & 71.233 & 5050254.000 & 440 \\
\hline Assets (Million rupees) & 177529.900 & 1867003.000 & 2500.300 & 272971.100 & 440 \\
\hline Ln(Investment) & 10.423 & 14.237 & 4.913 & 1.869 & 440 \\
\hline Ln(Wages) & 6.338 & 16.093 & 1.845 & 1.885 & 440 \\
\hline Ln(Price of financial capital) & -2.591 & 7.550 & -9.837 & 1.437 & 440 \\
\hline Ln(Price of physical capital) & -2.527 & 6.972 & -6.834 & 1.655 & 440 \\
\hline
\end{tabular}

\section{RESULTS AND DISCUSSION}

We estimate invariant true fixed effect model and random effect model then use Hausman test to choice between true fixed effect and true random effect model. We accept the null hypothesis that true random effect model is consistent against alternative of true fixed effect model. The results of true random effect model of profit and cost functions are presented in table 2.

All the variables show the expected impact on profit and cost. Input prices have negative impact on profit of the banks as expected.

Table-2. Estimation results of Profit and cost frontier models

\begin{tabular}{|c|c|c|}
\hline Variable & LnProfit & LnTotal cost \\
\hline \multirow{2}{*}{$\mathrm{C}$} & $-4.57^{*}$ & $-6.575^{*}$ \\
\hline & $(0.000)$ & $(0.000)$ \\
\hline \multirow{2}{*}{ Ln(Wage) } & -0.024 & $0.138 *$ \\
\hline & $(0.143)$ & $(0.000)$ \\
\hline \multirow{2}{*}{ Ln(Price of financial capital) } & $-0.0222^{*} *$ & 0.042 \\
\hline & $(0.025)$ & $(0.307)$ \\
\hline \multirow{2}{*}{ Ln(Price of Physical capital) } & -0.043 & $-0.07 * *$ \\
\hline & $(0.215)$ & $(0.032)$ \\
\hline \multirow{2}{*}{ Ln(investment) } & $0.156^{* * *}$ & $0.115^{*}$ \\
\hline & $(0.024)$ & $(0.005)$ \\
\hline \multirow{2}{*}{ Ln(assets) } & $0.892^{*}$ & $0.880^{*}$ \\
\hline & (0.000) & (0.000) \\
\hline \multirow{2}{*}{ Ln(loans) } & $0.079^{*}$ & $0.277^{*}$ \\
\hline & $(0.002)$ & $(0.000)$ \\
\hline \multirow{2}{*}{ Wald Chi square Statistic } & $970.120 *$ & 797.230* \\
\hline & $(0.000)$ & $(0.000)$ \\
\hline
\end{tabular}

In parenthesis p-values are given. ${ }^{*}, * *$ and ${ }^{* * *}$ indicate $1 \%, 5 \%$ and $10 \%$ level of significance.

Outputs have positive impact on profit and this implies that as output increases the profits of the banks also increase. However magnitude of the coefficient of lnassets is higher than other output 
variables following investment and loans to total assets. Price of labor or wages does not have statistically significant impact on profit before tax. Coefficients of price of physical capital $\left(L n P_{k}\right)$ and price of financial capital have negative and statistically significant effect in profit before tax of commercial banks.

We also estimate the cost function of the banks using maximum simulated likelihood method. Coefficients of input prices have positive and significant impact on total cost of the banks. As factor input price increases, cost increases. Investment, loans to assets ratio and total assets have positive and statistically significant influence on total cost of the bank. These results are consistent with economic literature.

We have estimated the average efficiency of 22 commercial banks. Average profit efficient of commercial banks is $73.04 \%$ whereas cost efficiency is $85.10 \%$. This comparative analysis clearly indicates that commercial banks are more cost efficient than profit efficient. Furthermore we divide commercial banks into foreign banks, private commercial banks and state owned commercial banks and profit efficiency is reported in table 3 .

Table-3. Mean profit efficiency of commercial banks

\begin{tabular}{l|c|c}
\hline & Profit efficiency & St. dev. \\
\hline Commercial Banks & 0.730 & 0.157 \\
\hline Foreign Banks & 0.833 & 0.407 \\
\hline Private Banks & 0.703 & 0.162 \\
\hline State Owned Banks & 0.218 & 0.265 \\
\hline
\end{tabular}

Table 3 shows that foreign banks are $83.3 \%$ profit efficient following private banks that are $70.30 \%$ and then state owned commercial banks are $21.80 \%$. Alternative, it is true that State owned banks are least profit efficient banks. Hence policy of deregulation and privatization has provided the level playing field for both foreign and private domestic banks. Annual profit efficiencies of overall commercial banks, foreign banks, private banks and state owned banks are calculated and reported in table 4 .

Due to implementation of privatization policy, profit efficiency of commercial banks increased over the time, though variation exists in profit efficiency. Similarly, efficiency of foreign of foreign and private banks increased over the time and after the financial reforms, private banks and foreign banks are functioning very close to the efficiency frontier. Hence less output oriented inefficiency prevails in the private commercial banks and foreign banks.

However opposite trend is observed in the profit efficiency of state owned banks. They are performing below the efficiency frontier and are less efficient compared to foreign and private commercial banks. Similarly, we estimate the cost efficiency of banks to compare it with profit efficiency. On average commercial banks are $92.31 \%$ cost efficient and $73.04 \%$ profit efficient. In figure 2 , we show the trend of cost efficiency and profit efficiency.

We observe that commercial banks move to cost efficiency frontier during the period of the study. Indeed it is worth mentioning that cost efficiency of commercial banks has improved over the time $1995-2014$. 
Table-4. Annual profit efficiency

\begin{tabular}{|c|c|c|c|c|}
\hline Years & Foreign Banks & Private Banks & $\begin{array}{c}\text { State Owned } \\
\text { Banks }\end{array}$ & All Commercial Banks \\
\hline 1995 & 0.490 & 0.804 & 0.009 & 0.713 \\
\hline 1996 & 0.714 & 1.062 & 0.522 & 0.967 \\
\hline 1997 & 0.763 & 0.952 & 0.225 & 0.948 \\
\hline 1998 & 0.665 & 0.807 & 0.008 & 0.794 \\
\hline 1999 & 0.836 & 0.831 & 0.824 & 0.897 \\
\hline 2000 & 0.538 & 0.770 & 0.650 & 0.784 \\
\hline 2001 & 0.693 & 0.635 & 0.232 & 0.670 \\
\hline 2002 & 0.684 & 0.550 & 0.017 & 0.584 \\
\hline 2003 & 0.622 & 0.514 & 0.436 & 0.530 \\
\hline 2004 & 1.870 & 0.737 & 0.453 & 0.938 \\
\hline 2005 & 0.339 & 0.723 & 0.008 & 0.655 \\
\hline 2006 & 0.538 & 0.521 & 0.008 & 0.526 \\
\hline 2007 & 0.555 & 0.693 & 0.086 & 0.657 \\
\hline 2008 & 1.543 & 0.780 & 0.128 & 0.945 \\
\hline 2009 & 0.939 & 0.789 & 0.085 & 0.866 \\
\hline 2010 & 0.687 & 0.794 & 0.036 & 0.746 \\
\hline 2011 & 0.734 & 0.631 & 0.008 & 0.602 \\
\hline 2012 & 0.887 & 0.523 & 0.009 & 0.560 \\
\hline 2013 & 1.711 & 0.499 & 0.615 & 0.743 \\
\hline 2014 & 0.856 & 0.447 & 0.008 & 0.484 \\
\hline
\end{tabular}

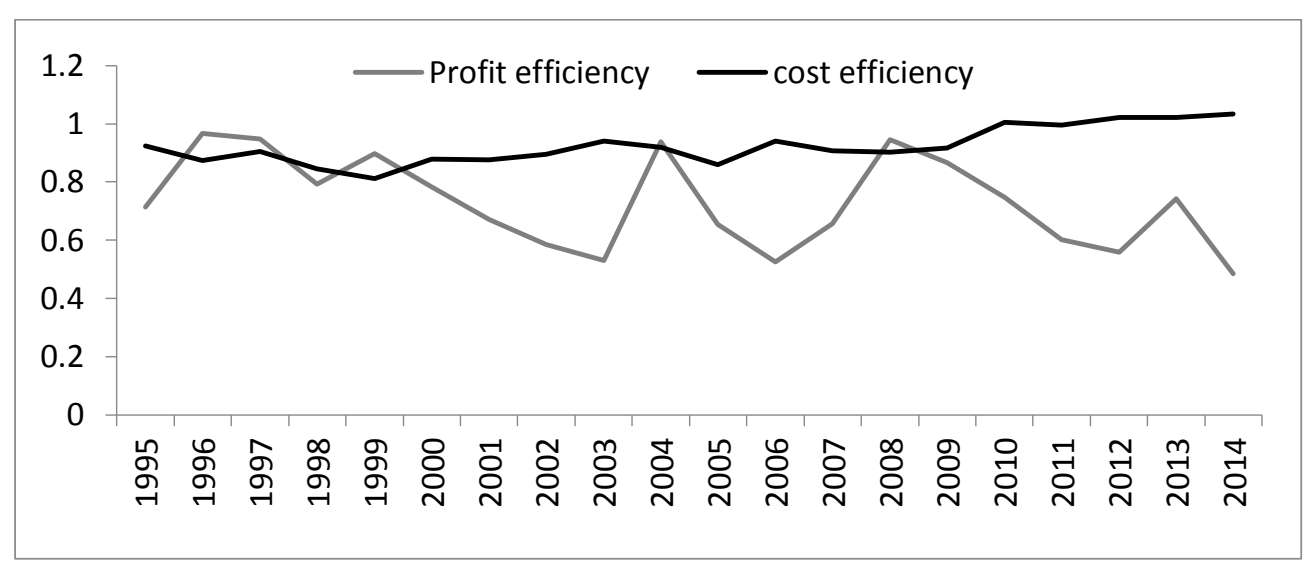

Figure-2. Cost and profit efficiency

\section{CONCLUSIONS}

The aim of this paper was to estimate the profit efficiency of commercial banks of Pakistan by using stochastic frontier approach based on true fixed effect and true random effect models on balanced panel of 22 commercial banks over the period 1995-2014. Unlike many other studies Greene (2005a) approach was employed to capture inter-banks heterogeneity exists among banks. Another objective of the paper was to assess the profit efficiency of foreign banks, private domestic banks and state owned banks to see what happened after privatization. We also compared the cost and profit efficiency of over all commercial banks in Pakistan. We found that commercial banks are 73\% profit efficient and $27 \%$ percent profit inefficient. After the implementation of financial reforms, the profit efficiency of commercial banks has increased. This clearly indicates privatization has 
provided the level playing field to the commercial banks operating in Pakistan to become cost and profit efficient.

Our results show that, on average foreign banks demonstrate high level of profit efficiency, followed by private domestic banks and then state owned banks. This finding justified perceived wisdom that the policy of privatization and deregulation makes foreign and private domestic banks profit efficient. Our results also suggest that continuation of liberalization policy has obvious merits in term of output oriented efficiency of foreign and private domestic banks. Hence we can say that policy of bank privatization and restructuring is justified on economic grounds. Other developing countries may learn lesson from privatization and restructuring policy of Pakistan to liberalize their banking sector to cope with the challenges of globalization and economic integration (Burki and Niazi, 2010).

Furthermore, we compare the cost and profit efficiency of over all commercial banks of Pakistan. We find that the commercial banks are more cost efficient than profit efficient. This implies that inefficiency on the part of cost is less than profit inefficiency. Interesting thing is that both cost efficiency and profit efficiency increase over the time. This shows that the policy of privatization has positive impact on efficiency of banks. This has made commercial banks in Pakistan prudent and efficient in term of their performance and these banks can absorb any type of financial shock.

Funding: This study received no specific financial support.

Competing Interests: The authors declare that they have no competing interests.

Contributors/Acknowledgement: All authors contributed equally to the conception and design of the study.

\section{REFERENCES}

Akhavein, J. D., Swamy, P. A. V. B., \& Taubman, S. (1997). A general method of deriving the efficiencies of banks from a profit function. Journal of Productivity Analysis, 8, 71-91.

Akmal, M., \& Saleem, M. (2008). Technical efficiency of the banking sector in Pakistan. SBP Research Bulletin, 4(1), 61-80.

Altunbas, Y., Evans, L., \& Molyneux, P. (2001). Bank ownership and efficiency. Journal of Money, Credit and Banking, 33(4), 926-954.

Altunbas, Y., Gardener, E. P. M., Molyneux, P., \& Moore, B. (2001). Efficiency of European banking. European Economic Review, 45, 1931-1955.

Battese, G. E., \& Coelli, T. J. (1995). A model for technical inefficiency effects in stochastic frontier production function for panel data. Empirical Economics, 20(2), 325-332.

Bauer, P. W., \& Ferrier, G. D. (1996). Scale economies, cost efficiencies, and technical change in federal reserve payments processing. Journal of Money, Credit, and Banking, 28(4), 10041039.

Berger, A. N. (1993). Distribution-free' estimates of efficiency in the U.S. banking industry and tests of the standard distributional assumptions. Journal of Productivity Analysis, 4(3), 26192.

Berger, A. N., \& Mester, L. J. (1997). Inside the black box: what explains differences in the Efficiencies of financial Institutions?. Journal of Banking \& Finance, 21, 895-947.

Berger, A. N., Leusner, J. H., \& Mingo, J. J. (1997). The efficiency of bank branches. Journal of Monetary Economics, 40, 141-162.

Burki, A. A., \& Ahmad, S. (2010). Bank governance changes in Pakistan: is there a performance effect? Journal of Economics and Business, 62, 129-146.

Burki, A. A., \& Niazi, G. S. K. (2009). Impact of financial reforms on efficiency of state-owned, private and foreign banks in Pakistan. Applied Economics, 42(24), 3147-3160.

Chakravarty, S. P., \& Williams, J. (2006). How significant is the alleged unfair advantage enjoyed by state owned banks in Germany. Cambridge Journal of Economics, Oxford University Press, $30(2), 219-226$.

Debreu, G. (1951). The coefficient of resource utilization. Econometrica, 19(3), 273-292. 
Farrell, M. J. (1957). The measurement of production efficiency. Journal of Royal Statistical Society, 120, 253-290.

Greene, W. (2005a). Reconsidering heterogeneity in panel data estimators of the stochastic frontier model. Journal of Econometrics, 126, 269-303.

Hardy, D. C., \& Patti, E. B. D. (2001). Banking reforms and bank efficiency in Pakistan. IMF working paper No. WP/01/138. Washington, D.D: IMF.

Hasan, I., \& Marton, K. (2003). Development and efficiency of the banking sector in a transitional economy: Hungarian experience. Journal of Banking and Finance, 27, 2249-2271.

Hughes, J. P., \& Mester, L. J. (1993). A quality and risk-adjusted cost function for banks: evidence on the too-big-to-fail doctrine. Journal of Productivity Analysis, 4, 293-315.

Hughes, J. P., Lang, W., Mester, L. J., \& Moon, C. G. (1995). Recovering technologies that account for generalized managerial preferences: an application to non-risk-neutral banks. Working Paper No. 95-8/R, federal Reserve Bank of Philadelphia.

Hughes, J. P., Lang, W., Mester, L. J., Moon, C. (1996a). Efficient banking under interstate branching. Journal of Money, Credit and Banking, 28, 1045-1071.

Humphrey, D. B., \& Pulley, L. B. (1997). Banks' responses to deregulation: profits, technology and efficiency. Journal of Money, Credit and Banking, 29(1), 73-93.

Iimi, A. (2004). Banking sector reforms in Pakistan: economies of scale and scope, and cost complementarities. Journal of Asian Economics, 15, 507-528.

Isik, I., \& Hassan, M. K. (2002). Technical, scale and allocative efficiencies of Turkish banking industry. Journal Banking and Finance, 26(4), 719-766.

Koopmans, T. (1951). Activity analysis of production and allocation. John Wiley \& Sons, New York.

Kumbhakar, S. C. (2006). Productivity and efficiency measurement using parametric econometric methods. In: Bagella M, Becchetti L, Hasan I (eds) Transparency, governance, and markets. Elsevier, Oxford, pp. 21-61.

Kumbhakar, S. C., Lozano-Vivas, A., Knox, L. C. A., \& Hasan, I. (2001). The effect of deregulation on the performance of financial institutions: the case of Spanish banks. Journal of Money, Credit and Banking, 33(1), 101-120.

Levine, R. (1997). Financial development and economic growth: views and agenda. Journal of Economic Literature, 35, 688-726.

Maudos, J., Pastor, M. J., Perez, F., \& Quesada, J. (2002). Cost and profit efficiency in European banks. Journal of International Financial Markets, Institutions and Money, 12, 33-58.

McFadden, D. L. (1966). Cost, revenue, and profit functions: a cursory review. Working Paper No. 86, Institute for Business and Economic Research, University of California, Berkeley, mimeographed.

Mullineaux, D. J. (1978). Economies of scale and organizational efficiency in banking: A profit function approach. Journal of Finance, 33, 317-330.

Patti, E. B. D., \& Hardy, D. C. (2005). Financial sector liberalization, bank privatization, and efficiency: Evidence from Pakistan. Journal of Banking \& Finance, 29, 2381-2406.

Phang, S., \& Raweewan, M. (2015). A study of cost, revenue and profit efficiency of commercial banks in Cambodia using DEA approach. Recent advances and future prospects in knowledge. Information and Creativity Support System, 685, 168-178.

Poshakwale, S. S., \& Qian, B. (2011). Competitiveness and efficiency of the banking sector and economic growth in Egypt. African Development Review, 23(1), 99-120.

Qayyum, A., \& Khan, S. (2007). X-efficiency, scale economies, technological progress and competition: a case of banking sector in Pakistan. PIDE Working Papers.

Ray, C. S., \& Das, A. (2010). Distribution of cost and profit efficiency: evidence from Indian banking. European Journal of Operational Research, 201, 297-307.

Reddy, K. S., \& Nirmala, V. (2013). Profit efficiency and its determinants: Evidence from Indian commercial banks. Journal of Transnational Management, 18(2), 125-163.

Rizvi, S. F. A. (2001). Post-liberalization efficiency and productivity of the banking sector in Pakistan. The Pakistan Development Review, 40(4), 605-632. 
Sabir, S., \& Qayyum, A. (2018). Competition in the banking sector of Pakistan: evidence from unscaled and scaled revenue equation. Journal of Economic Cooperation and Development, 39(1), 19-37.

Sealey, C. W. Jr., \& Lindley, J. T. (1977). Inputs, outputs, and a theory of production and cost of depository financial institutions. The Journal of Finance, 32(4), 1251-1266.

Shepherd, R.W. (1970). Theory of cost and production functions. Princeton University Press, Princeton, New Jersey.

State Bank of Pakistan (2005). Financial assessment report 2005. State Bank of Pakistan, Karachi.

Vivas, A. L. (1997). Profit Efficiency for Spanish Saving banks. European Journal of Operational Research, 98, 381-394.

Views and opinions expressed in this article are the views and opinions of the author(s), Journal of Asian Business Strategy shall not be responsible or answerable for any loss, damage or liability etc. caused in relation to/arising out of the use of the content. 